further south. The age of the latter is not precisely known (probably it is Pliocene) and no fossils have so far been found in the gravels, but the possibility of correlating the two is tempting.

Should further work substantiate these findings and suggestions, then we may postulate Recent marine transgression extending as far as the Najaf area-almost halfway up the present delta.

Alwiyah Club,

BAGHDAD, IRAQ.

28 th November, 1957.

\title{
REFERENCES
}

(1) Hudson, R. G. S., F. E. Eames, and G. L. Wilkins, 1957. The Fauna of Some Recent Marine Deposits Near Basrah, Iraq. Geol. Mag., xciv, 393-401.

(2) LeEs, G. M., and N. L. FALCON, 1952. The Geographical History of the Mesopotamian Plains. Geogr. Journ., cxviii, 24-39.

(3) Mrtchell, R. C. (In press.) Recent Tectonic Movements in the Mesopotamian Plains. Geogr. Journ.

Raoul C. Mitchell.

\section{NAMURIAN STAGE NAMES}

SiR,--In a recent paper Dr. F. Hodson (1957) has most usefully discussed and correlated the various faunal bands occurring in the West European Namurian in the lower part $\left(R_{1} a\right)$ of the Kinderscoutian Stage and the upper part (Ha) of the Sabdenian Stage, and redescribed and figured some of the goniatites that occur therein. He has also proposed the replacement of the well-established Namurian stage Sabdenian (Homoceras Age, $\mathrm{H}$ ) by two stages: an upper one which he equates with the Homoceras eostriolatum zone $(\mathrm{Hb})$, the upper zone of the Sabdenian, and names Alportian; and a lower one which he equates with the $H$. beyrichianum zone (Ha), the lower zone of the Sabdenian, and names Chokierian. The stage names used for the Namurian before the publication of Dr. Hodson's paper have been accepted and widely used since their erection in their current form by Hudson and Cotton (1943). If chaos is to be avoided, changes in the nomenclature of stages should only be accepted for the most cogent of reasons, and it is, therefore, surprising to find that no reasons for his proposed changes are given by Dr. Hodson in his paper.

The name Sabdenian (founded Bisat, 1928, p. 126; redefined Hudson and Cotton, 1943, p. 152) was based on the formation Sabden Shales. The type section of the upper part of the Homoceras age was chosen by Bisat $(1924$, p. 49) as that exposed at Roughlee, east of Pendle Hill, Lancashire. There in the upper part of the Sabden Shales all the faunal bands typical of the upper zone $(\mathrm{Hb})$ of the Sabdenian are exposed (Bisat, 1924, p. 49 ; Bisat and Hudson, 1943, p. 399 ; Hodson, 1957, p. 14). The change in the name of the upper part of the Sabdenian to Alportian also carries the implication that rocks of this age are well exposed at Alport in Derbyshire, which will become the typical sections for beds of this age. The exposures in Alport Dale, however, are incontestably worse than those at Roughlee.

There may be better reasons for using sections in the Assise de Chokier as typical of the lower part of the Sabdenian, but even in this case the biostratigraphical succession can be demonstrated in the Sabden Shales in Lancashire, and a change seems unnecessary.

It therefore seems to us that Dr. Hodson's proposed changes are unnecessary and even retrograde, and that the Sabdenian should be retained as a stage name within the Namurian. 


\section{REFERENCES}

BISAT, W. S., 1924. The Carboniferous goniatites of the north of England and their zones. Proc. Yorks Geol. Soc., xx, 40.

1928. The Carboniferous goniatite zones of England and their continental equivalents. Congr. de Strat. Carb., Heerlen, for 1927, 117.

and R. G. S. Hudson, 1943. The Lower Reticuloceras $\left(\mathbf{R}_{1}\right)$ goniatite succession in the Namurian of the north of England. Proc. Yorks Geol. Soc., xxiv, 383.

Hodson, F., 1957. Marker horizons in the Namurian of Britain, Ireland, Belgium, and Western Germany. Ass. Etud. Paléont. no. 24, 26 pp., Bruxelles.

Hudson, R. G. S., and G. Cotton, 1943. The Namurian of Alport Dale, Derbyshire. Proc. Yorks Geol. Soc., xxv, 142.

R. G. S. HudSON,

Irak Petroleum Co., Ltd., 214 OXFord STREet, LONDON, W. 1.

21 st January, 1958.
W. H. C. RAMSBOTTOM,

Geological SURVEY AND MUSEUM, EXHIBITION ROAD, LONDON, S.W. 7.

\section{REVIEWS}

Glacial and Pleistocene Geology. By R. F. Flint. xiii +553 pp., 138 figs., 5 pls., 51 tables. John Wiley and Sons, Inc., New York, 1957. (Chapman and Hall, Ltd., London.) Price $£ 5$.

In his preface Professor Flint says that this book began as a revision of his Glacial Geology and the Pleistocene Epoch, published in 1947, but that the vast amount of work done on the subject since that time necessitated a new book rather than a mere revision.

The book can indeed be regarded as new. Much material has been added, on $\mathrm{C}^{14}$ chronology and " $\mathrm{O}^{18}$ temperatures", on pollen-analysis, soils, frozen-ground phenomena, and many other topics. Much must also have been removed, for the book is shorter than its predecessor by thirty-six pages, but this seems to have achieved more by general condensation than by the removal of entire passages. In addition, there have been extensive rearrangements. The most important are in the chapters on glaciology, which have been largely rewritten in an attempt to make them "more meaningful in glacial geology"; particularly useful here are special studies of the Greenland and Antarctic ice-sheets, included for the light they may throw on former ice-sheets elsewhere. In all parts of the book material has been shifted about in the interests of a more logical arrangement, and few individual sentences survive without alterations, if only to their punctuation.

These changes seem to be entirely successful. It need only be added that the book retains all the admirable stylistic qualities of Flint (1947): clarity, conciseness, and absence of unnecessary jargon (" hypsithermal " may be unlovely but is certainly not unnecessary). One hopes that Professor Flint will feel obliged to publish a similar volume in 1967.

R. W. H. 